\title{
STRATEGY FOR THE DEVELOPMENT OF JOINT TERRITORIAL GROUPS: THEO- RETICAL ASPECTS
}

Iryna Bovsunivska, Candidate of Economic Sciences, Associate Professor of the Department of Public management and administration Educational-Scientific Institute of Management, Economics and nature use of V.I. Vernadsky Taurida National University Kyiv (Ukraine)

ORCID: https://orcid.org/0000-0003-3962-4534

Email: bovsan@gmail.com

\begin{abstract}
The purpose of this article is a theoretical and methodological analysis of strategic planning of the united territorial community in conditions of decentralization of power and local self-government reform.

The methodological basis is the general aspects of the economic theory and theory of public administration. Methods of research are based on general scientific and special methods of cognition. System, structural and evolutionary approaches are used to identify the essence of the categories "territorial community", "the capacity of the territorial community" and "strategy of development of the territorial community"; the methods of analysis and synthesis allowed to reveal the peculiarities of strategic planning of the development of the united territorial communities, the abstract-logical method was used for theoretical generalization and formation of conclusions.

The main aspects and results of the research are applied in the educational process in the development and teaching of normative and special courses "Economics and Governance", "Decentralization and development of territorial communities", "Public-private partnership" at the V.I. Vernadsky Taurida National University for the master's students Public Administration program.

The scientific novelty is as follows:

1. With the addition of systemic, structural and evolutionary approaches, it is found that the definition of the term "territorial community" should take into account historical, territorial, ecological, sociological, selfgoverning, economic and political aspects. The concept of "capacity of a territorial community" is defined as the ability to perform the functions entrusted by the legislation directly to the community and local self-government authorities to ensure its life and development. The configuration of the capacity of the territorial community was substantiated, its components (internal and external capacity) were clarified.

2. The principles and stages of strategic planning of the development of a united territorial community under conditions of decentralization of power and local self-government reform, which are important for the success of the strategic planning of territorial development are considered. It is proved that the principles should be considered in close connection with a certain stage of the strategy of the development of the united territorial communities. The algorithm of strategic planning of the development of a united territorial community based on the principles of strategic planning of sustainable development of territories is proposed.

3. It is grounded that the effectiveness of the strategy of the development of united territorial communities depends to a large extent on the way of its development. Practical experience in creating strategies in Ukraine has identified five methods for developing strategic plans for the development of territories, of which the long-term partnership method (three partnerships between government, community and business) with the participation of experts is most effective. This description of each method is given, their strengths and weaknesses are determined.

4. It is grounded that in the conditions of the reform of local self-government the issue of formation of updated (project) competencies of local self-government employees becomes relevant. At the present stage, the demand for a new style of thinking of managers is being formed, the continuation of which is an updated organizational culture of management, the traditional qualifications of today's local government officials are not enough to work in new environments where the project becomes a leading tool for change, achievement of goals, funding unit and one the main means of attracting additional resources to the united territorial communities.

The main results can be used by public authorities and authorities, local government authorities, research
\end{abstract}


centres and institutes, and higher educational institutions (proposals for the organization of strategic planning of the development of united territorial communities through institutions of mediation of power, business and community).

Keywords: decentralization; territorial community; united territorial community; capacity; external and internal capacity; development; partnership; strategic planning.

Received: 15.04 .2019

Accepted for publication: 13.05 .2019

Published: 18.06.2019

Bovsunivska, I. (2019). Strategy for the Development of Joint Territorial Groups: Theoretical Aspects. Bulletin of Taras Shevchenko National University of Kyiv. Public Administration,(11), 5-16. https://doi.org/10.17721/2616-9193.2019/11-1/7

Problem statement and its connection with important scientific and practical tasks. In modern conditions, strategic planning of the socio-economic development of the united territorial community becomes a prerequisite for increasing their competitiveness. The development of strategic planning of territories is due to the presence of a number of trends: 1) global - the impact of globalization, the strengthening of territorial competition between territories for investment, etc .; 2) national - administrative (implementation of administrative reform and decentralization of state power, formation of a system of regulation and management of the development of territories in the conditions of decentralization; development of the legal and regulatory framework for strategic planning); economic (the existence of economic imbalances in the development of territories at the regional and local levels, etc.); social (increasing differentiation by territories according to the level of incomes, wages, receiving social, communal, administrative services, development of social infrastructure); ecological (differentiation in the ecological state of territories; availability of territories with high level of environmental pollution, insufficient development of ecological infrastructure, excessive man-caused environmental impact); 3) local - the transfer of more power and resources to the level of territorial communities; increasing the role of regional and local decision-making levels; strengthening the responsibility of local authorities for improving the quality of public services; increase of public activity in the process of solving urgent problems of local development, in the development and implementation of strategic plans.

Principally, the process of developing strategies for the development of a united territorial community is not complex character, and not always strategic documents are aimed at addressing the actual problems of the development of local communities, having a formal or descriptive character. It can be stated that methodological, normative-legal, personnel, informational and resource support of the strategies of the development of a united territorial community at the local level are only beginning to take shape in Ukraine; should create regulatory, economic, organizational, informational, social mechanisms of strategic planning of territories.

Analysis of recent research and publications. The basis for the development of strategic planning at the regional and local level is the work of Ukrainian and foreign experts in the area of public administration. Thus, the problems of state governance of regional and local development were widely investigated by Ukraininan scientists, primarily V. Babayev, S. Bila, V. Kuibida, S. Rogatchev, S. Varnaliy, V. Vorotin, and others. Among the researchers of the development of territories should be distinguished O. Karyi, O. Lukyanchenko, V. Mamonov, O. Shyrokov, S. Yurkovб G. Vetrov. The practical and theoretical aspects of the functioning of the mechanisms of public administration in the area of strategic planning of territorial development are considered in the works of O. Berdanova, I. Dunaev, Y. Ivashkov, M. Latinin, T. Lozynska, P. Mavk, O. Panunhnik, B. Parkhomenko, P. Proshkщo, I. Sanzharovskyi, V. Tertychka, V. Vakulenko.

Along with the significant studies, the issues of creating a project management methodology are remain unexplored and do not have a practical implementation. They have a number of peculiarities that impede the application of a well-known foreign experience: the lack of project management practices among representatives of local self-government authorities; unbalanced budgets of the united territorial communities; lack of effective monitoring practices. All this determined the urgency and necessity of conducting researches to im- 
prove the strategies of the united territorial community taking into account the current trends and needs of the development of territories, the concept of sustainable development.

The purpose of the study. The purpose of this article is a theoretical and methodological analysis of strategic planning of the united territorial community in conditions of decentralization of power and local self-government reform.

Description of the methodology of the study. The methodological basis is the general aspects of the economic theory and theory of public administration. Methods of research are based on general scientific and special methods of cognition. System, structural and evolutionary approaches are used to identify the essence of the categories "territorial community", "the capacity of the territorial community" and "strategy of development of the territorial community"; the methods of analysis and synthesis allowed to reveal the peculiarities of strategic planning of the development of the united territorial communities, the abstract-logical method was used for theoretical generalization and formation of conclusions.

Presenting main material. The theoretical comprehension of the notion of "community" is due today to the pressing problems of society. This is due to the fact that the community has an important role in its management at the current stage of development of the state. The issue of the role of territorial communities is becoming increasingly relevant in the context of improving the administrative-territorial system (ATS), whose task is facing the country in the period of important socio-political transformations aimed at achieving a higher level of socioeconomic and cultural development, the creation of an effective system of territorial management [Titenko Z.V. 2007: 13]. In this context, it is important to have a correct scientific identification of the notion of "territorial community" as the basic category of reforming the territorial organization of power on the basis of decentralization.

The Constitution of Ukraine [the Constitution of Ukraine, 1997] and the Law of Ukraine "On Local SelfGovernment in Ukraine" [On Local Self-Government in Ukraine, 1997] consolidated the main aspects of territorial communities in the system of local self-government. In accordance with the Constitution of Ukraine, the territorial community is defined as the primary subject of local self-government. According to Art. 140 [Constitution of Ukraine, 1997] local self-government is the right of a territorial community - residents of a village or a voluntary association in a village community of residents of several villages, settlements and cities - to independently solve issues of local importance within the Constitution and laws of Ukraine. The Law of Ukraine "On Local SelfGovernment in Ukraine" [On Local Self-Government in Ukraine, 1997] contains the following definition: the territorial community is "residents who are united by permanent residence within the village, settlement, city, which are independent administrative-territorial units, or voluntary association of residents of several villages having a single administrative center".

It should be noted that the Constitution of Ukraine and the Law of Ukraine "On Local SelfGovernment in Ukraine" take into account such features as territorial order and self-governing approach. To my mind, the definition of the term "territorial community" should take into account historical, territorial, ecological, sociological, self-governing, economic and political aspects.

Thus, the notion of "territorial community" is characterized by the following main features: 1) territorial - the joint residence of members of a community in a certain territory; 2) integrative - a territorial community arises on the basis of the association of all residents of a particular territory, regardless of whether they are citizens of this state; 3) cultural and historical - traditions, features of historical development, historical connections between inhabitants of the territory and between separate territories; 4) intellectual - the basis of the constitution of the territorial communities is the common interests of the inhabitants, which are of a specific nature and are manifested in the form of a wide range of systemic individual-territorial ties; 5) self-government - the right of the territorial community to implement local self-government is enshrined in the Constitution and in the Law of Ukraine "On Local SelfGovernment in Ukraine"; 6) property - the territorial community is the subject of the right of communal property; 7) fiscal - members of a territorial community are payers of local taxes and fees.

The territorial community is a complex "cumulative" form of a public organization, a group of people (local residents) associated on a public basis within a certain territory, united by diverse features of a systemic nature (in particular, demographic and territorial (communal) ties, legal and political connection, property (economic) and professional communication, linguistic and religious (social and cultural connection, etc.). This association, which does not exclude the human right to individuality, separate housing and leisure, consolidates efforts many to achieve the desired result. 
As in other European countries, where the reform of the administrative-territorial entities has already been carried out, the purpose of this reform in our country is: 1) creation of territories capable of development; 2) providing high-quality services of the population; 3) creation of conditions for personnel growth in local self-government. The current reform of the administrative-territorial system has two principal conditions for its implementation: 1) the reform of the administrative-territorial system should take place through voluntary association of territorial communities; 2) new united territorial communities should be able to.

Capable territorial communities - territorial communities of villages (settlements, cities), which, as a result of a voluntary association, are capable of providing, on their own or through appropriate local self-government authorities, the appropriate level of provision of services, in particular in the fields of education, culture, health care, social protection, housing -communal economy, taking into account personnel resources, financial support and infrastructure development of the corresponding administrative-territorial unit [On Approval of the Methodology of Formation ..., 2015].

Thus, community capacity means the ability to perform the functions entrusted by law to the community and local governments directly to ensure its livelihoods and development [Olshansky, 2016: 4].

The internal capacity of the community includes the following components: 1) legal - the ability of the community as a whole to use its rights to solve the issues of the functioning and development of the local community, as well as the ability of individual citizens to use legal instruments to resolve personal problems; 2) material and environmental - the capacity of utilities, the use of land and other natural resources, the state of the environment; 3) organizational - the optimal organizational structure of local governments in the community, the presence of a true leader and managers of the relevant qualifications; 4) economicinvestment - business environment, investment attractiveness; 5) financial - the existence of stable sources of revenues to the local budget, sufficient to finance current and capital expenditures; 6) infrastructure - roads, constructions, engineering communications (cables and power lines, gas, heat, water supply and drainage), transport network, communications, etc.; 7) humanitarian and social - a network of educational, health, cultural, physical culture and sports institutions; 8) public - the level of participative democracy, mechanisms of public participation.

The external capacity of the community is characterized by the following components: 1) legislative definition of the sphere of local government activities (local issues), distribution of powers in the system of public administration between public administration authorities and local self-government authorities, etc .; 2) political - efforts to consolidate society, the existence of political will of the authorities to strengthen the role of local self-government in social development; 3) administrative - implementation of not only democratic decentralization, as well as deconcentration in the system of public administration; 4) territorial - elimination of the disadvantages of the current territorial system, ensuring universality of local self-government; 5) macroeconomic - the state of economic and social development of the country as a whole (GDP per capita, inflation, unemployment, etc.); 6) state-financial - balance of the state budget, mechanism of formation of inter-budgetary relations; 7) intermunicipal - the development of intermunicipal cooperation; 8) societal - a characteristic of society as a system with a complex network of collective and groups (social strata), which have different status and play a different role in the life of society, but are interconnected and interact in a holistic way (systemic development of society).

Obviously, the state of the territorial community is never static, it is always in the process of development. Development may seem like a peculiar, philosophical concept. However, we operate with him almost every day - when we want our country to develop one way or another when we complain that something is underdeveloped when we say that something has developed so or not when we think about the growth of family income and the development of children [Zveryakov, 2017: 48].

Economic development is always around us and we are right in the center. Development, both at the local level and at the national level, is one of the most important concepts of economic science. In the literature, the term "socio-economic development" is often used, thus emphasizing the close connection between the level of economic development and the solution of the social problems of the country.

Socio-economic development is a complex contradictory process in which positive and negative factors interact, and periods of progress are replaced by periods of regression. Political and military upheavals, social conflicts, environmental disasters can halt the development of any country's economy, reject it for several 
decades, and sometimes lead to ultimate death, as was the case with ancient civilizations. Economic development can and must be managed - it needs to be stimulated. Such basic tools for stimulating the development of territorial communities are cooperation and association, which have already received some support. First of all, in order for the growth of financial resources of local self-government to ensure their effective use for the development of communities and their territories, the process of voluntary association of the communities is gaining momentum.

It is aimed exclusively at the creation of capable communities, those that provide a high standard of living for its inhabitants. The formation of capable territorial communities is one of the stages of the implementation of the decentralization reform in Ukraine. One of the main objectives of the territorial communities association is economic efficiency. Therefore an important factor in this process should be the scientifically grounded formation of a strategy for the development of territorial communities. In modern economic literature, the term "development strategy" is not correct defined and is associated with evolution, both with economic growth and with the process of achieving the main goal. In today's unstable economic situation, the strategy needs to be considered, firstly, as a set of tactics that can and should change if the dynamics of the external or internal environment does not meet projections (with the invariability of the ultimate goal, which usually involves further growth), secondly, the strategy must be inextricably linked with such a concept as development. When forming a strategy for the development of a united territorial community, it is necessary to take into account external and internal conditions, the availability of resources and opportunities and risks that must necessarily be foreseen.

The development strategy should focus first and foremost on improving competitiveness and a favorable investment climate. In this way, the strategy acts not only as a tool for substantiating, developing and implementing the goals, objectives of the industrial, scientific, technical, economic, organizational and social nature, not only as a factor regulating the activity of a territorial community until the goals and objectives are set to be achieved, but at the same time as a means of communicating the community with the market environment. The consequence of this approach to strategy formation is the development strategy document, which for a local government authorities, as well as entrepreneurs and community partners, is a kind of guide to decision-making. Therefore, the strategy for the development of a united territorial community should be understood as a long-term plan that outlines the general direction of action of local authorities and their partners (business sector, community organizations, residents), and presents ways and means of implementing it. The developed assumptions of the development strategy substantiate the methodological, financial and organizational decisions taken by the authorities.

Strategy of development of the united territorial community is a document of strategic planning that defines strategic and operational goals for the long-term (5-7 years) period, tasks for sustainable economic and social development of the united territorial community, which is developed taking into account the provisions of the Law of Ukraine "On Principles of State Regional Policy" and the Resolution of the Cabinet of Ministers of Ukraine dated November 11, 2015, No. 932 "On Approval of the Procedure for the Development of Regional Development Strategies and Action Plans for their Real as well as monitoring and evaluating the effectiveness of the implementation of these regional strategies and action plans" [Vasilchenko G., 2015: 130].

The strategy is the most important document of the local self-government authorities, which allows to distinguish own actions against the background of everyday life. The strategy for the development of a united territorial community should be characterized by several essential features: - it focuses on those areas of community development that make it the greatest chance for the future; - characterized by accurate, logical record, which follows from the strategic directions of development in the system: strategic goals, operational objectives, tasks for implementation; - outlines the competitive advantages of the community in relation to the near and far-away environment - creates a strategy for dynamic development; - is the result of the work of representatives of all groups of the community, ranging from local authorities, organizations and institutions to councils and ending with residents. This allows you to get goals and targets from all stakeholders, as well as local community representatives' perceptions of the decisions and tasks that are taken as part of the strategy; - linked to other documents of a strategic character.

The strategy should be based on the following principles:

1. Institutionalization - the process of strategic planning of the development of a united territorial community is carried out with the help of special institutions (authorities, structures). 
2. Objectivity - relying on previous achievements, experience and objective information.

3. Competence - ensuring compliance with the range of issues addressed by the strategy and competences of the strategic planning units of the united territorial community. Availability of sufficient level of knowledge, ability, skills and experience to the performers.

4. Social partnership - cooperation of state authorities with all representatives of the territorial community in the process of strategic planning of the development of a united territorial community.

5. Scientific justification - availability of scientific methodology and methodology of strategic planning of the development of a united territorial community.

6. Eligibility and hierarchy - the process of strategic planning of the development of a united territorial community must be in line with current legislative and regulatory documents in the existing hierarchy system.

7. Priority is the inclusion in the strategy of the main directions, implementation of which will enable harmonious development of the territory.

8. Goal setting is a correct statement of purpose and strategic objectives.

9. System and complexity in the process of strategic planning of the united territorial community - the territory of the united territorial community is considered as a complex system for solving economic, social and environmental problems. According to the principle of systematic, in the process of formation and implementation of the state regional policy, national, regional and local interests should be taken into account in a mutual connection; the task of developing all spheres of public life, its optimal territorial organization, all essential factors.

10. Alternative - working out of alternative variants at development of strategy.

11. Coordination and coherence - spatial coordination of goals, priorities and actions of central, regional and local executive authorities, local self-government authorities; all normative-legal documents of different levels.

12. Complex provision of strategic planning for the development of a united territorial community availability of normative-legal, methodological and methodical, organizational, resource, social, informational support of strategic planning of the development of a united territorial community.

13. Effectiveness - directing all the measures put into the strategy to achieve the goals.

14. Efficiency - the definition of the quantitative expression of the ratio of costs and results of improving the economic, ecological and social status of the territory.

15. Flexibility and adaptability - taking into account the possibility of changing the internal and external environment of the territory.

16. Transformation - the strategy should be developed specific programs and projects, as mechanisms for implementing the strategy. The strategy is transformed into specific programs and plans.

17. Concentration - due to the limited resources of concentration on solving the most urgent tasks of the territory development.

18. Synchronization - harmonization of priorities and actions of central, local authorities, local governments in relation to regional and local development.

19. Step-by-step - phased implementation of individual partial tasks depending on the already achieved indicators of socio-economic development of territories.

20. Legitimacy - recognition of the right of the authorities to manage all processes carried out in a particular territory; agreement, readiness of members of the territorial community to make decisions and plans.

The algorithm of strategic planning of the development of a united territorial community taking into account the principles of strategic planning of territories development:

1. Preparatory stage for the organization of work on strategic planning of the development of a united territorial community (SPDUTC) - principles: $5,6,7 ; 8,9,10.1$ ) the creation of an initiative working group of SPDUTC; 2) involvement of experts and consultants (if necessary); 3) identification of interested parties (stakeholders) in the creation of SPDUTC. Formation of a public council; 4) elaboration of a plan for involving the public in the process of SPDUTC. Distribution of roles among the participants of the SPDUTC; 5) the creation of a working authorities of the SPDUTC, a public coordination council for local development; 6) development of the system of organizational, material, financial, information and other provision of SPDUTC; 7) elaboration of the work plan of the SPDUTC working group; 8) clarification of the theoretical 
basis of SPDUTC. Development of the concept of SPDUTC; 9) the choice of methodological and methodological support for the process of SEDP, the definition of roles and responsibilities in the process of EAPR.

2. Strategic Planning Stage - principle 10.

2.1. Analytical stage 1) analysis of the external and internal situation; list of the most important problems of the territory; 2) development of the profile and passport of the territorial community; 3) determining the place of the territorial community in the raion, region, Ukraine; 4) prioritizing the problems of the territorial community, determining its capabilities; implementation of SWOT, PEST, EPISTEL, STIPLE, ABC analyzes.

2.2. Stage of development of strategic documents - principles: $7,8,10 ; 11,14.1$ ) formulation of the mission, strategic vision. Development of scenarios for events development; 2) development options strategy development and the choice of optimal strategy. Define strategic goals and operational actions to achieve strategic goals. Develop an action plan to achieve each goal. Defining indicators to characterize the achievement of each goal; 3) Creating a program and plan as documents. Development of programs, projects and tasks.

3. Stage of assessment of the quality of strategic documents, approval and adoption of strategic documents principles: 10,11.

4. Stage of implementation (implementation of strategic documents) - principles: 11; 12; 13; 16; 19.

4.1. Realization of tasks of strategic documents;

4.2. Information on the progress of implementation of strategic documents of local self-government authorities, population (public), regional and state authorities.

5. Stage of periodic monitoring and evaluation of the results of implementation of strategic documents principles: $13 ; 14$.

6. Post-program stage - performance analysis, implementation report, discussion of results of implementation of strategic documents with the public - principles: 13; 14.

7. The stage of making changes and adjusting strategic documents is the principle: 15.

Creation of a strategic plan for local development is not an end in itself and is not only done for a document or process (although the chosen process method is important), it is a tool that helps raise the competitiveness of a community, city or region, rationally use limited resources, attract local human potential, provide synergistic effect, to create conditions for future growth of territory and welfare of the population. The effectiveness of the strategy largely depends on how it is developed. From the practical experience of creating strategies in Ukraine [Experience of Formation and Implementation of the Development Strategy ..., 2010], five methods of developing strategic development plans can be identified, of which the long-term partnership method (three partnerships) with the participation of experts is most effective.

Analysis of existing methods for developing strategies for the development of the territory:

1. The method of paternalism (administrative method).

Characteristic of the method: the strategy is developed by the authorities and municipal management.

Strong positions of the method: 1) it is relatively easy to exercise control over the implementation of the strategic plan; 2) guarantees of implementation of the positions of the strategic plan, because what is planned is that it is easy to execute; 3 ) does not require additional funds for strategy development.

Weak position of the method: 1) one-sided approach and narrowed vision of community development and its future; 2) underdeveloped development opportunities and ultimate goals; 3) often the strategy has a formal character; 4) the potential of local business and public organizations is not used; 5) the absence is the effect of synergy in the community and the principle of endurance.

2. Administrative and consulting method.

Characteristic of the method: The strategy is developed by the authorities and the municipal management with community involvement advice (round tables, public hearings, questionnaires, etc.).

Strong positions of the method: 1) it is relatively easy to exercise control over the implementation of the strategic plan; 2) guarantees of implementation of the positions of the strategic plan, because what is planned is that it is easy to execute; 3) transparency is ensured for the authorities, the strategy formally has the appearance of a democratic document; 4) there is a chance to take into account community proposals; 5) the presence of a general direction of development and the possible participation of business and public organizations.

Weak position of the method: 1) The administrative approach prevails; 1) it is relatively easy to exercise control over the implementation of the strategic plan; 2) guarantees of implementation of the positions of the 
strategic plan, because what is planned is that it is easy to execute; 3) transparency is ensured for the authorities, the strategy formally has the appearance of a democratic document; 4) there is a chance to take into account community proposals; 5) The effect of synergy and the principle of emergence is very weak; 6) The possibility of inconsistency and unresolved conflicts between the community's desires and the power of the authorities.

\section{Expert method.}

Characteristic of the method: the strategy is developed by the involved experts, who professionally work on the development of strategies for the development of territorial communities.

Strong position of the method: 1) the strategy looks professional and attractive in terms of content and form; 2) the strategy takes into account the best experience of previous development and development tools; 3) the strategy is based on a fundamental analysis of the state of development and local capacity, takes into account; third-party view of the development of the territory.

Weak position of the method: 1 ) the risk of using templates in building strategies that take into account local specifics; 2) the plans and tasks, developmental possibilities and goals set are unrealistic; 3 ) not using the potential of local business and public organizations; 4) absent is the effect of synergy and the principle of an emergence.

\section{Expert-consultation method}

Characteristic of the method: developed by experts who, in the process of studying the environment and developing the main areas of development, seek advice (round tables, public hearings, questionnaires, etc.) to the local community (business, public organizations, etc.) and authorities.

Strong position of the method: 1) the strategy looks professional and attractive in terms of content and form; 2) the strategy takes into account the best experience of previous developments and development tools; 3 ) the strategy is based on a fundamental analysis of the state of development and local capacity, takes into account; third-party view of the development of the territory; 4) transparency is ensured for the authorities, the strategy formally has the appearance of a democratic document; 5) there is a chance to take into account community proposals; 6) the effect of synergy and the principle of the emergence is very weak;

Weak position of the method: 1) a small chance to implement the strategy. 2) the strategy has a formal character; 3) The authorities easily find arguments justifying non-fulfillment; 4) The effect of synergy and the principle of emergence is very weak; 5) The possibility of inconsistency and unresolved conflicts between the wishes of the community and the power of the authorities.

\section{The method of long-term partnership (three partnerships) with the participation of experts.}

Characteristic of the method: The concept of the method is based on the form of a group of professionals (leaders of local communities, business and government) that is working on developing a development strategy with the help of the involved independent experts.

Strong position of the method: 1) the strategy looks professional and attractive in terms of content and form; 2) the strategy takes into account the best experience of previous developments and development tools; 3 ) the strategy is based on a fundamental analysis of the state of development and local capacity, takes into account; third-party view of the development of the territory; 4) triggers the effect of synergy and the principle of an emergence that ensures the effectiveness of the strategy; 5) current activities of local public organizations and business coincide with the objectives of the community strategic plan; 6) transparency is ensured for the authorities, confidence in local authorities is growing; 7) the physical and financial resources of power, business, community are effectively used; 8) maximize the intellectual potential of the community as a whole, and its individual representatives in particular.

Weak position of the method: 1) difficulties arise with the search for consensus and the coordination of the positions of understanding and action of the three sectors of the community (power, business, public organizations); 2) it is expensive, it requires more money to pay for experts (research, training, development documents, etc.) and the organization of the process itself.

In order for a strategic plan to work for the development of a local community, it must be created and implemented by the community. Only when local business, the active community and the authorities are developing the strategy can hope that local people will perceive the strategy as their own plan of action. Work on the principles of partnership between representatives of local authorities, business and the community forms a systematic tool for reaching the consensus of the three sectors of society and managing change developments. The involvement of 
third-party experts (specialists) into work greatly increases the importance of the process of developing a document, guides the actions of the participants and gives them confidence in making the right decisions. Consequently, strategic planning is a powerful method of systematic activity to combine the efforts of the active community, business community and government in the private-public partnership, working on the formation of a favorable business climate, increasing the competitiveness of the local community and solving issues related to the level the life of all the inhabitants of the community. Power and active community in this sense are the engine for creating favorable conditions for business development, and the business itself is the engine of local development.

And one more important question. The reform of local self-government generates numerous changes in territorial communities that concern almost all aspects of their activities. Of course, changes will affect local government officials. This is already proved by the experience of the first united territorial communities. In other words, the question of the formation of updated competencies of local self-government employees becomes absolutely topical. It seems appropriate to pay special attention to the design competencies of local government officials. In general, today, in public administration, extreme activity in the application of the project approach is observed. The integration of strategic and project tools has become a fact, as a result of which the strategies of the development of joint territorial communities are formed in such a way that the implementation of strategic priorities is carried out through the use of projects (project and program portfolios).

Among the proposed rosters of the structure of the executive committee of the united territorial community is the attention of the position of the project manager. Its introduction testifies to a radical increase of the role and significance of strategic and project activity in the united territorial community, which is one of the key in terms of ensuring effective and effective development and cooperation of communities. For the same purpose, in the structure of the executive committee of the united territorial community, it is proposed to create a working group (team) for strategic development and investment attractiveness of the united territorial community.

Another important fact that determines the actuality of the project officers' acquisition of local selfgovernment officials. One of the key figures of a united territorial community should be the head of state - a leader and speaker of the interests of the public in the territories annexed to the united territorial communities. The elder must demonstrate professionalism, strategic vision and active state position regarding the development of the village, the focus on the application of modern standards, methods and tools for managing the development of the territory. He should have the competence to discuss areas and measures for socio-economic development of the territory, be able to make realistic proposals to the plan of socio-economic development of the community, have the ability to implement relevant decisions aimed at solving the problems of the village, to focus on the priorities of strategic development, preparation and implementation of the development strategy and program of socio-economic development of the territory, to be able to analyze the development projects developed by the executive committee, conducts consultations with deputies and the public to work out complex strategic questions of the development of the territory, to form working groups, to know the best examples and practices of solving actual problems, to be able to take into account the opinion of various stakeholders and social groups, to involve interested parties in the processes of preparation of strategies, projects and plans, be able to efficiently use the initiative of residents as a mechanism for implementing authorities, link strategic planning of community development and budget, etc.

Another important accent. International certification of project managers under the IPMA version includes taking into account not only the qualification component (knowledge, ability, skills), not only their own abilities and experience, creative activity, and such a specific component as a personal position. In addition to the above, the latter implies the ability to generate ideas, to form a critical view of professional problems, to have an opinion, to present it and to defend it. This fundamentally separates the traditional style of thinking from creative, design, which in essence is problematic. The problematic style of thinking is today on the agenda in the united territorial community, where a lot of changes are being made on solving painful problems. The project approach to problem solving is a convenient and useful tool in a changing environment, where it is often unavoidable to perform non-typical and non-repetitive, potentially conflicting works. The project approach is the response to the need for a transition from a problem to a problematic thinking style that is urgently needed today as a result of the need to solve problems that can not be foreseen in advance in the job descriptions of local self-government officials during the initial regulation of the local selfgovernment authorities. That is, inevitably the demand for a new style of thinking of managers is formed, the continuation of which is a renewed organizational culture of governance, based on adhocratic approaches. Thus, it is clear from the above that the traditional qualifications of today's local government officials are not 
enough to work in new environments where the project becomes a leading instrument of change, goal achievement, funding unit and one of the main means of attracting additional resources to the united territorial communities. .

Conclusions and perspectives of further research. The strategy of local development is a priority strategy of economic development of cities and regions aimed at increasing the competitiveness of the territorial community. The development of economic development strategies of a city or region should be based on six such postulates: 1. Economic development is created by business. 2. Workplaces ensure the welfare of the community and affect the growth of both individual incomes of residents and the growth of the aggregate social product. 3. Local authorities and public organizations create conditions for business development. 4. Developed infrastructure is a predominant element of community competitiveness. 5. Quality services provided by local authorities to the community and business are an element of competitive advantage. 6 . Efficient city or regional governance is provided through system management, local resources, stakeholder engagement and tripartite partnership. Strategic planning, in terms of process and methodology, is a complex instrument for influencing the economic future of the community. It requires a clear algorithm, political will and knowledge of local government, community readiness and understanding. When developing the strategic plan, the existing conditions are reviewed, the forces that influence the local economy are analyzed, the specific measures to be taken and the changes that are expected to affect the local economy are being developed. The process is complicated by its selectivity and the need for concerted action and consensus-seeking, since the opportunities and resources available in the community are always limited, and the task-setting task itself should be based on identifying and selecting the problems and developing the action plans that are most prioritized and effective.

The study of the theoretical and practical aspects of developing strategies for the development of united territorial communities can not be limited to this article. We hope that the present article will encourage other (especially Ukrainian) scientists to contribute to solving these problems in Ukraine.

\section{References}

Vasilchenko, G., Parasiuk, I. \& Eremenko, N. (2015). Planning the development of local communities. A manual for local government officials.Kyiv, Ukraine: LLC " ENTERPRISE " V N A ", 256.

Ilko Kucheriv "Democratic Initiatives" foundation (2016), "Decentralization: Results, Challenges and Prospects", available at: http://dif.org.ua/article/detsentra( lizatsiya(rezulbtati(vikliki(i(perspektivi (Accessed 15 March 2017).

Slava, S., Hoblyk, V., Popadynets, M., Luksha, A., Stankevich, O. \& Gritsak, L. (2010). Experience of formulation and implementation of development strategy Transcarpathian region by 2015, with the participation of the community. Slava, S., Hoblyk, V., Popadynets, M. (Ed). Kyiv, Ukraine: "KIS", 144.

Zverjakov M.I., Koval'ov A. I. and Smentina N. V. (2017) Strategichne planuvannja zbalansovanogo rozvitku teritorial'nih social'no-ekonomichnih sistem $\mathrm{v}$ umovah decentralizacii [Strategic planning of balanced development of territorial social and economic systems in the minds of decentralization], Odesa, ONEU, Ukraine.

Ol'shans'kij O. V. (2016) Spromozhnist' gromad v aspekti teoretiko-prikladnoï identifikaciï / O. V. Ol'shans'kij. - Teorija ta praktika derzhavnogo upravlinnja . - №4(55) . - 2016. - S. 1-6.

Konstitucija Ukraïni vid 28.06.1996 r. - K. : Presa Ukraïni, 1997. - 80 s.

Cabinet of Ministers of Ukraine (2015). Pro zatverdzhennya Metodyky formuvannya spromozhnykh terytorial'nykh hromad [On approval of methodologies capable of forming local communities]. Resolution on 2015, Aprilr 08, 214. Retrieved from http://zakon2.rada.gov.ua/laws/show/214- 2015-p. 
Pro misceve samovrjaduvannja v Ukraïni : Zakon Ukraïni № 280/97-VR vid 21.05.1997 r. // Vidomosti Verhovnoï Radi Ukraïni. - 1997. - № 24. - S. 170.

Titenko Z.V. Suspil'no-geografichni aspekti administrativno-teritorial'nogo ustroju oblasnogo regionu (na prikladi Odes'koï oblasti) : avtoref. dis. ... kand. geogr. nauk : 11.00.02. Odesa, 2007. 20 s.

\title{
СТРАТЕГІЯ РОЗВИТКУ ОБ’ЄДНАНИХ ТЕРИТОРІАЛЬНИХ ГРОМАД: ТЕОРЕТИЧНИЙ АСПЕКТ
}

\begin{abstract}
Ірина Бовсунівська, кандидат економічних наук, дочент кафедри публічного управління та адміністрування Навчально-наукового інституту управління, економіки та природокористування Таврійського національного університету імені В. І. Вернадського (Україна)

ORCID: https://orcid.org/0000-0003-3962-4534
\end{abstract}

Email:bovsan@gmail.com

Отримано: 15.04 .2019

Ухвалено до друку: 13.05 .2019

Опубліковано: 18.06 .2019

Бовсунівська I. (2020). Стратегія розвитку об’єднаних територіальних громад: теоретичний аспект. Вісник Київського начіонального університету імені Тараса Шевченка. Державне управління, (11), 5-16. https://doi.org/10.17721/2616-9193.2019/11-1/7

\section{Анотація}

Мета дослідження. Метою даної статті є здійснити теоретико-методологічний аналіз стратегічного планування розвитку об’єднаної територіальної громади в умовах децентралізачії влади та реформи місиевого самоврядування.

Методика. Методологічну основу складають загальні положення економічної теорії та теорії публічного управління. Методи дослідження грунтуються на загальнонаукових і спеціальних методах пізнання. Системний, структурний та еволючійний підходи використано для виявлення сутності категорій "територіальна громада", "спроможність територіальної громади" та "стратегія розвитку територіальної громади"; методи аналізу та синтезу дозволили виявити особливості стратегічного планування розвитку об'єднаних територіальних громад, абстрактно-логічний метод був використаний для теоретичного узагальнення й формування висновків.

Результати. Основні положення і результати дослідження застосовуються у навчальному прочесі при розробиі та викладанні нормативних і спещіальних курсів "Економіка та врядування", "Децентралізачія та розвиток територіальних громад", "Публічно-приватне партнерство" в Таврійському начіональному університеті імені В. І. Вернадського для слухачів магістерської програми "Публічне управління та адміністрування".

Наукова новизна. Наукова новизна полягає в наступному:

1. За допомогою системного, структурного та еволючійного підходів виявлено, що дефінічія поняття "територіальна громада" повинна враховувати історичний, територіальний, екологічний, сочіологічний, самоврядний, економічний та політичний аспекти. Визначено поняття "спроможність територіальної громади" як здатність виконувати функиії, покладені законодавством безпосередньо на громаду та на органи місчевого самоврядування щодо забезпечення ї̈ життєдіяльності та розвитку. Обгрунтовано конфігуращію спроможності територіальної громади, з’ясовано їі складові (внутрішня та зовнішня спроможність).

2. Розглянуто принципи та етапи стратегічного планування розвитку об’єднаної територіальної громади в умовах дещентралізачіі влади та реформи місиевого самоврядування, що мають важливе значення для успішності процесу стратегічного планування розвитку територій. Доведено, що принципи 
необхідно розглядати в тісній прив'язиі до певного етапу стратегї̈ розвитку об'єднаних територіальних громад. Запропоновано алгоритм проведення стратегічного планування розвитку об'єднаної територіальної громади з урахуванням приниипів стратегічного планування сталого розвитку територій.

3. Обгрунтовано, що в умовах реформи місцевого самоврядування актуальним стає питання формування оновлених (проектних) компетентностей службовиів місиевого самоврядування. На сучасному етапі формується запит на новий стиль мислення управліниів, продовженням чого є оновлена організачійна культура управління, традииійних кваліфікаиій свогоднішніх посадових осіб місиевого самоврядування вже не вистачає для роботи в нових умовах, де проект стає провідним інструментом змін, досягнення иілей, одиницею фінансування та одним з основних засобів залучення додатковихресурсів до об’єднаних територіальних громад.

Практична значимість. Основні положення статті можуть застосовуватись органами державної влади та управління, органами місчевого самоврядування, науково-дослідними центрами та інститутами, вищими навчальними закладами (пропозищіі щодо організачї стратегічного планування розвитку об’єднаних територіальних громад через інституиії посередництва влади, бізнесу та грома$\partial u)$.

Ключові слова: децентралізачія, територіальна громада, об’єнана територіальна громада, спроможність, зовнішня та внутрішня спроможність, розвиток, партнерство, стратегічне плануванHq. 